\title{
Lechevalieria fradiae sp. nov., a novel actinomycete isolated from soil in China
}

\author{
Correspondence \\ Jianli Zhang \\ zhangjianli@bit.edu.cn \\ Zhiheng Liu \\ zhliu@sun.im.ac.cn
}

\author{
Jianli Zhang, ${ }^{1}$ Qiong Xie, ${ }^{2}$ Zhiheng Liu ${ }^{3}$ and Michael Goodfellow ${ }^{4}$ \\ ${ }^{1}$ School of Life Science and Technology, Beijing Institute of Technology, Beijing 100081, \\ People's Republic of China \\ ${ }^{2}$ Institute of Space Medico-Engineering, Beijing 100094, People's Republic of China \\ ${ }^{3}$ State Key Laboratory of Microbial Resources, Institute of Microbiology, Chinese Academy of \\ Sciences, Beijing 100101, People's Republic of China \\ ${ }^{4}$ School of Biology, University of Newcastle, Newcastle upon Tyne NE1 7RU, UK
}

The genus Lechevalieria was proposed by Labeda et al. (2001) to accommodate aerobic, Gram-positive actinomycetes that form an extensively branched substrate mycelium and scant aerial hyphae, and contain meso-diaminopimelic acid in whole-organism hydrolysates (wall chemotype III sensu Lechevalier \& Lechevalier, 1970), galactose, mannose and rhamnose as diagnostic sugars, tetrahydrogenated menaquinones as the predominant isoprenologue, phosphatidylethanolamine as the key polar lipid (phospholipid type II sensu Lechevalier et al., 1977) and fatty acids rich in saturated and monounsaturated iso- and anteisocomponents. The genus encompasses two species, Lechevalieria aerocolonigenes, the type species, and Lechevalieria flava; these taxa form a distinct branch within the evolutionary radiation occupied by the family Actinosynnemataceae Labeda and Kroppenstedt 2000. This family also contains the genera Actinosynnema Hasegawa et al. 1978, Lentzea Labeda et al. 2001 and Saccharothrix Labeda et al. 1984.

The present investigation was designed to establish the taxonomic position of a soil organism, isolate $\mathrm{Z6}^{\mathrm{T}}$, which had been considered by Xunchu Yan in 1978 (unpublished) to be a strain of 'Streptomyces fradiae' on the basis of a few biochemical, morphological and physiological properties.

The GenBank/EMBL/DDBJ accession number for the 16S rRNA gene sequence of strain $Z 6^{\top}$ is $A Y 114175$.
Here, a polyphasic taxonomic approach was used to study this isolate; the data showed that it should be recognized as a representative of a novel species of Lechevalieria.

Strain $\mathrm{Z6}^{\mathrm{T}}$ was isolated on a glucose-yeast extract-malt extract agar plate, which had been seeded with a soil suspension and incubated at $28^{\circ} \mathrm{C}$ for 2 weeks. The soil sample was collected from Wutaishan Mountain in Shanxi Province, China. It was maintained on modified Sauton's agar (Mordarska et al., 1972) at $4{ }^{\circ} \mathrm{C}$ and as suspensions of mycelial fragments in $20 \%(\mathrm{v} / \mathrm{v})$ glycerol at $-20{ }^{\circ} \mathrm{C}$. Biomass for the chemotaxonomic and molecular systematic studies was prepared as described by Zhang et al. (2002).

Extraction of genomic DNA, PCR-mediated amplification of the 16S rRNA gene and purification of the PCR product from isolate $\mathrm{Z6}^{\mathrm{T}}$ were carried out after Rainey et al. (1996) and the PCR product was sequenced directly following the procedure described by $\mathrm{Lu}$ et al. (2001). The resultant $16 \mathrm{~S}$ rRNA gene sequence was aligned manually with corresponding sequences of representatives of genera classified in the suborder Pseudonocardineae retrieved from the DDBJ/ EMBL/GenBank databases using CLUSTAL_X 1.8 software (Thompson et al., 1997). Phylogenetic trees were generated using the least-squares, maximum-likelihood and neighbourjoining algorithms from the PHYLIP suite of programs (Felsenstein, 1993); evolutionary distance matrices for the 
least-squares and neighbour-joining methods were produced after Kimura (1980). Topologies of the resultant unrooted trees were evaluated by bootstrap analyses of the neighbour-joining dataset based on 1000 resamplings using the SEQBOOT and CONSENSE options from the PHYLIP package. In a corresponding second analysis, the sequence of the tested strain was compared with those of members of genera classified in the family Actinosynnemataceae.

It is apparent from Fig. 1 that strain $\mathrm{Z6}^{\mathrm{T}}$ forms a distinct phyletic line that lies towards the periphery of the Lechevalieria $16 \mathrm{~S}$ rRNA clade. It shared $16 \mathrm{~S}$ rRNA gene similarities of 98.4 and $98.0 \%$ with the type strains of
L. aerocolonigenes and L. flava, respectively, values that correspond to 22 and $28 \mathrm{nt}$ differences at 1407 positions. It is also significant that the 16S rRNA gene sequence of the isolate includes signature nucleotides that are characteristic of members of the genus Lechevalieria (Labeda et al., 2001), the family Actinosynnemataceae (Labeda \& Kroppenstedt, 2000) and the suborder Pseudonocardineae (Stackebrandt et al., 1997).

The isolate was examined for a range of chemotaxonomic markers to determine whether its chemical profile was typical of members of the genus Lechevalieria (Labeda et al., 2001). Standard chromatographic procedures were used for

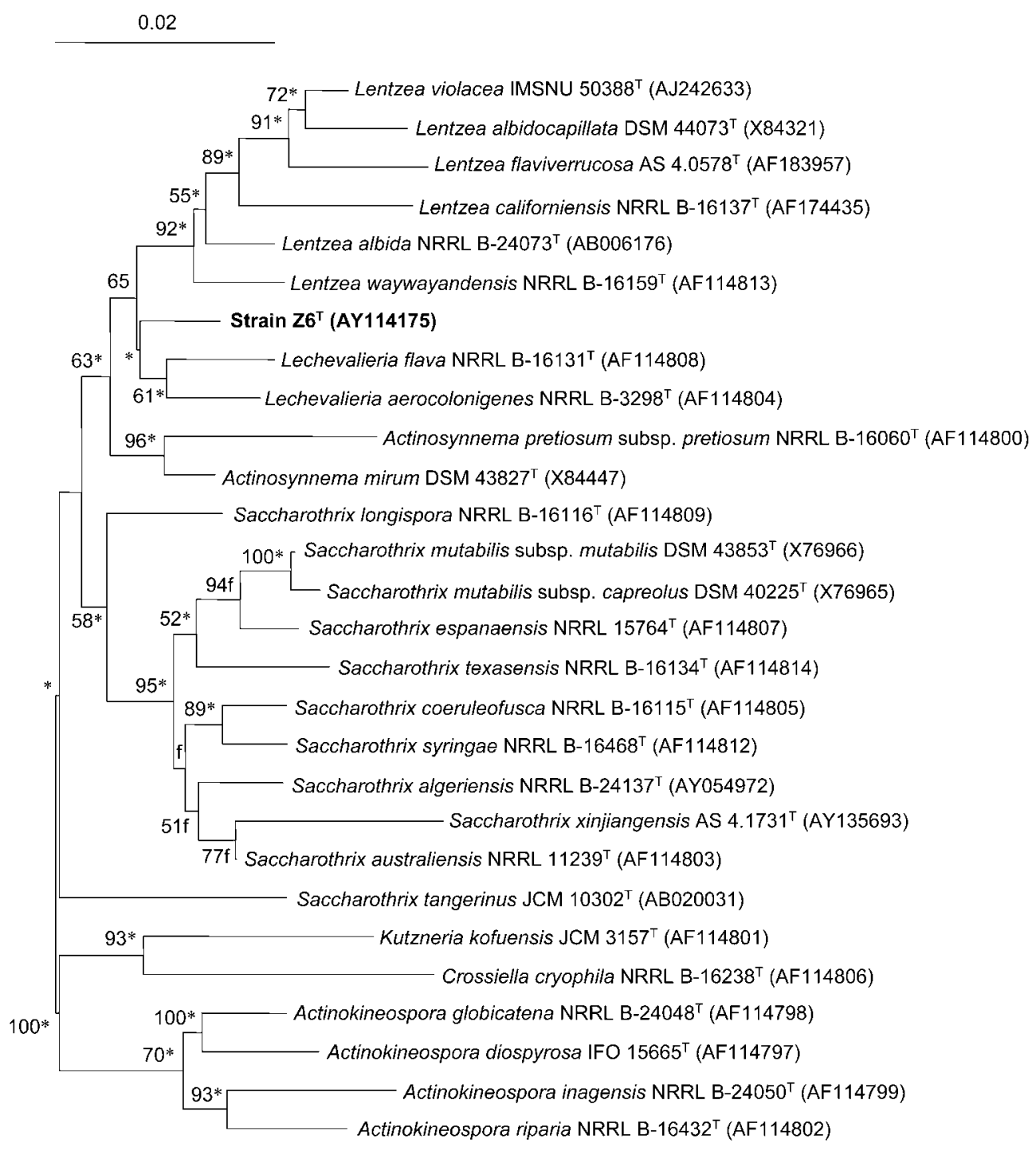

Fig. 1. Neighbour-joining tree based on nearly complete $16 \mathrm{~S}$ rRNA gene sequences showing relationships between strain $\mathrm{Z6}^{\top}$ and representatives of known species classified in genera assigned to the family Actinosynnemataceae. Asterisks indicate branches of the tree that were also recovered using the least-squares and maximum-likelihood tree-making algorithms; ' $\mathrm{f}$ ' denotes branches of the tree that were recovered using the least-squares method. Numbers at nodes indicate the levels of bootstrap support based on a neighbour-joining analysis of 1000 resampled datasets; only values above $50 \%$ are given. Bar, 0.02 substitutions per nucleotide position. 
the extraction and analysis of the diagnostic isomers of diaminopimelic acid ( $\mathrm{A}_{2} \mathrm{pm}$; Hasegawa et al., 1983), menaquinones (Collins et al., 1987; Wu et al., 1989), mycolic acids (Minnikin et al., 1975), polar lipids (Minnikin et al., 1984) and whole-organism sugars (Lechevalier \& Lechevalier, 1980), using appropriate controls. In turn, fatty acids were extracted, purified, methylated and quantified by GC using the standard Microbial Identification System (MIDI; Sasser, 1990; Kämpfer \& Kroppenstedt, 1996). The base composition of the genomic DNA of the isolate was determined using the thermal denaturation method (Marmur \& Doty, 1962) with Escherichia coli AS 1.365 as the control. The organism contained: meso- $\mathrm{A}_{2} \mathrm{pm}$ as the wall diamino acid; galactose, mannose and rhamnose as diagnostic sugars; tetrahydrogenated menaquinones with nine isoprene units as the predominant isoprenologue and dihydrogenated menaquinones with nine isoprene units as the minor isoprenologue (peak area MK-9 $\left(\mathrm{H}_{4}\right):$ MK- $9\left(\mathrm{H}_{2}\right)$ ratio of 27:10); phosphatidylethanolamine and diphosphatidylglycerol as the key polar lipids; and fatty acids rich in saturated and mono-unsaturated iso- and anteisocomponents. However, strain $\mathrm{Z6}^{\mathrm{T}}$ lacked mycolic acids. The $\mathrm{G}+\mathrm{C}$ content of the DNA of the isolate was $68.0 \mathrm{~mol} \%$. All of these properties are consistent with the classification of the isolate in the genus Lechevalieria.

Colonial and micromorphological properties were examined on glucose-yeast extract-malt extract agar, modified Sauton's agar (Mordarska et al., 1972) and on standard media used in the International Streptomyces Project (ISP; Shirling \& Gottlieb, 1966). Micromorphological features were observed using the coverslip technique of Kawato \& Shinobu (1959) following the procedure described by Zhou et al. (1998). Peptone-yeast extract-iron agar and tyrosine agar plates (Shirling \& Gottlieb, 1966) were examined for the production of melanin pigments following incubation at $28^{\circ} \mathrm{C}$ for 14 days. Additional phenotypic properties were determined using standard media and methods (Gordon et al., 1974; Zhang et al., 2003). DNA-DNA relatedness studies were carried out between the isolate and the type strains of $L$. aerocolonigenes and $L$. flava using a thermal denaturation procedure (De Ley et al., 1970; Huß et al., 1983) with a UV-1206 spectrophotometer (Shimadzu) fitted with a TB-85 thermobath and standard software (Jahnke, 1992); the results were expressed as the mean of two determinations.

Strain $\mathrm{Z6}^{\mathrm{T}}$ exhibited phenotypic properties typical of members of the genus Lechevalieria (Labeda et al., 2001). It was an aerobic, Gram-positive, non-motile, catalasepositive actinomycete, which formed an extensively branched substrate mycelium that fragmented into coccoidand rod-shaped elements. The mean DNA-DNA hybridization values found between the isolate and the type strains of $L$. aerocolonigenes and L. flava were 45 and $37 \%$, respectively; values well below the $70 \%$ cut-off point recommended by Wayne et al. (1987) for the delineation of genomic species. The isolate could also be distinguished
Table 1. Differential phenotypic properties of strain $Z 6^{\top}$ and the type strains of the two Lechevalieria species

Strains: 1, strain $\mathrm{Z6}^{\mathrm{T}}$; 2, L. aerocolonigenes NRRL B-3298 ${ }^{\mathrm{T}}$; 3, L. flava NRRL B-16131 $1^{\mathrm{T}}$. Data were taken from this and previous studies (Labeda, 1986; Labeda et al., 2001; Grund \& Kroppenstedt, 1989). All strains grow at $37^{\circ} \mathrm{C}$. +, Positive; -, negative; W, weak; ND, not determined.

\begin{tabular}{|lccc|}
\hline Property & $\mathbf{1}$ & $\mathbf{2}$ & $\mathbf{3}$ \\
\hline Nitrate reduction & + & + & - \\
Decomposition of: & & & \\
$\quad$ Casein & + & + & - \\
$\quad$ Hypoxanthine & - & + & + \\
Production of acid from: & & & \\
$\quad$ Adonitol & - & + & W \\
Galactose & - & + & $\mathrm{ND}$ \\
Inositol & - & + & $\mathrm{ND}$ \\
Lactose & - & + & $\mathrm{ND}$ \\
Salicin & - & + & - \\
Assimilation of: & & & \\
Citrate & - & + & - \\
Lactate & + & + & - \\
Malate & + & + & - \\
Malonate & + & + & - \\
Oxalate & - & + & $\mathrm{ND}$ \\
Tartrate & - & + & $\mathrm{ND}$ \\
Growth on sole carbon sources: & & & \\
Sorbitol & + & - & - \\
Xylose & + & + & - \\
Growth in the presence of: & & & \\
$5 \%$ NaCl & + & + & - \\
$6 \%$ NaCl & & - & - \\
Growth at $45^{\circ} \mathrm{C}$ & & & + \\
\end{tabular}

from the two type strains using a combination of phenotypic properties (Table 1).

It is evident from the genotypic and phenotypic data that strain $\mathrm{Z6}^{\mathrm{T}}$ can be distinguished from the two known species of Lechevalieria. It is therefore proposed that the strain be classified in the genus Lechevalieria as Lechevalieria fradiae sp. nov.

\section{Description of Lechevalieria fradiae sp. nov.}

Lechevalieria fradiae (fra' di.ae. N.L. gen. n. fradiae of Fradia, a patronymic).

Aerobic, Gram-positive, catalase-positive, non-motile actinomycete. Forms an extensively branched substrate mycelium that fragments in situ into coccoid- and rod-shaped elements. A yellow to orange mycelium is formed on ISP media 2, 3 and 4, glucose-yeast extract-malt extract agar and modified Sauton's agar. Soluble pigments are not produced nor are melanin pigments formed on glucoseyeast extract-iron or tyrosine agars. Colony elevation is convex to irregular and colony margins are filamentous. 
Grows at $15-45^{\circ} \mathrm{C}$ and $\mathrm{pH} 5-10$. Aesculin, arbutin, gelatin and urea are hydrolysed and nitrate is reduced. $\mathrm{H}_{2} \mathrm{~S}$ is not produced. Degrades casein, starch and tyrosine, but not adenine, guanine, hypoxanthine or xanthine. Acid is formed from $(+)$-L-arabinose, meso-erythritol, methyl $\alpha$-D-glucoside, $(+)$-D-raffinose, $(+)$-D-trehalose and $(+)$-D-xylose, but not from $(+)$-D-cellobiose, dextrin, $(+)$-D-fructose, $(+)$-D-glucose, glycerol, (+)-D-maltose, $(+)$-D-mannitol, $(+)$-D-mannose, $(+)$-D-melezitose, $(+)$-D-melibiose, $\alpha$-Lrhamnose, $(+)$-D-sorbitol or (+)-D-sucrose. Sodium acetate, sodium lactate, sodium malate, sodium malonate and sodium succinate are used as sole carbon and energy sources, but not sodium benzoate, sodium citrate, sodium oxalate or sodium tartrate. Growth occurs in the presence of crystal violet $(0.001 \%, \mathrm{w} / \mathrm{v})$ and phenol at $0.05 \%(\mathrm{w} / \mathrm{v})$, but not in the presence of phenol at $0.1 \%(\mathrm{w} / \mathrm{v})$. Resistant to (in $\mu \mathrm{g} \mathrm{ml}^{-1}$ unless otherwise stated): lysozyme $(0.005 \%$, w/v); amoxycillin plus clavulanic acid (10); ampicillin (10); aztreonam (30); clindamycin hydrochloride (2); mezlocillin (75); and penicillin $\mathrm{G}$ (10 international units). Susceptible to (in $\mu \mathrm{g} \mathrm{ml}^{-1}$ ): amikacin (30); cefotaxime (30); chloramphenicol (30); ciprofloxacin (5); erythromycin (15); gentamicin sulfate (10); kanamycin sulfate (30); ofloxacin (5); rifampicin (5); streptomycin sulfate (10); tetracycline hydrochloride (30); and tobramycin sulfate (10). Additional phenotypic properties are shown in Table 1. Chemotaxonomic properties are typical of the genus Lechevalieria. The fatty acid profile is composed mainly of iso- $\mathrm{C}_{16: 0}(56.8 \%)$, iso- $\mathrm{C}_{14: 0}$ $(13.8 \%), \mathrm{H}$-iso- $\mathrm{C}_{16: 1}(12.3 \%), \mathrm{C}_{17: 1} \omega 6 c(3.5 \%)$, iso- $\mathrm{C}_{15: 0}$ $(3.3 \%)$ and $\mathrm{C}_{15: 1} \omega 6 c(3.0 \%)$.

The type strain is $\mathrm{Z6}^{\mathrm{T}}\left(=\mathrm{CGMCC} 4.3506^{\mathrm{T}}=\mathrm{JCM} 14205^{\mathrm{T}}\right)$, isolated from a soil sample collected from Wutaishan Mountain, Shanxi Province, China. The DNA G + C content of strain $\mathrm{Z6}^{\mathrm{T}}$ is $68.0 \mathrm{~mol} \%$. The species description is based on a single strain and hence serves as a description of the species.

\section{Acknowledgements}

This work was supported through the Royal Society-Chinese Academy of Sciences Exchange Scheme (grant number Q814), by the National Natural Science Foundation of China (NSFC, grant number 30570002) and by the Beijing Natural Science Foundation (grant number 5062024). The authors are grateful to Professor R. M. Kroppenstedt (DSMZ) and Dr T. Kudo (JCM) for the type strains of the Lechevalieria species, and to Dr Yajun Song for carrying out the quantitative fatty acid analysis on isolate $\mathrm{Z6}^{\mathrm{T}}$.

\section{References}

Collins, M. D., Howarth, O. W., Grund, E. \& Kroppenstedt, R. M. (1987). Isolation and structural determination of new members of the vitamin $\mathrm{K}_{2}$ series in Nocardia brasiliensis. FEMS Microbiol Lett 41, 35-39.

De Ley, J., Cattoir, H. \& Reynaerts, A. (1970). The quantitative measurement of DNA hybridization from renaturation rates. Eur J Biochem 12, 133-142.
Felsenstein, J. (1993). PHYLIP (phylogeny inference package), version 3.6. Department of Genome Sciences, University of Washington, Seattle, USA.

Gordon, R. E., Barnett, D. A., Handerhan, J. E. \& Pang, C.-H. N. (1974). Nocardia coeliaca, Nocardia autotrophica, and the nocardin strain. Int J Syst Bacteriol 24, 54-63.

Grund, E. \& Kroppenstedt, R. M. (1989). Transfer of five Nocardiopsis species to the genus Saccharothrix Labeda et al. 1984. Syst Appl Microbiol 12, 267-274.

Hasegawa, T., Lechevalier, M. P. \& Lechevalier, H. A. (1978). A new genus of Actinomycetales: Actinosynnema gen. nov. Int J Syst Bacteriol 28, 304-310.

Hasegawa, T., Takizawa, M. \& Tanida, S. (1983). A rapid analysis for chemical grouping of aerobic actinomycetes. J Gen Appl Microbiol 29, 319-322.

Huß, V. A. R., Festl, H. \& Schleifer, K. H. (1983). Studies on the spectrophotometric determination of DNA hybridization from renaturation rates. Syst Appl Microbiol 4, 184-192.

Jahnke, K. D. (1992). BASIC computer program for evaluation of spectroscopic DNA renaturation data from GILFORD SYSTEM 2600 spectrophotometer on a PC/XT/AT type personal computer. J Microbiol Methods 15, 61-73.

Kämpfer, P. \& Kroppenstedt, R. M. (1996). Numerical analysis of fatty acid patterns of coryneform bacteria and related taxa. Can J Microbiol 42, 989-1005.

Kawato, M. \& Shinobu, R. (1959). On Streptomyces herbaricolor sp. nov., supplement: a simple technique for microscopical observation. Mem Osaka Unit Lib Arts Educ B Nat Sci 8, 114-119.

Kimura, M. (1980). A simple method for estimating evolutionary rates of base substitutions through comparative studies of nucleotide sequences. J Mol Evol 16, 111-120.

Labeda, D. P. (1986). Transfer of 'Nocardia aerocolonigenes' (Shinobu and Kawato 1960) Pridham 1970 into the genus Saccharothrix Labeda, Testa, Lechevalier, and Lechevalier 1984 as Saccharothrix aerocolonigenes sp. nov. Int J Syst Bacteriol 36, 109-110.

Labeda, D. P. \& Kroppenstedt, R. M. (2000). Phylogenetic analysis of Saccharothrix and related taxa: proposal for Actinosynnemataceae fam. nov. Int J Syst Evol Microbiol 50, 331-336.

Labeda, D. P., Testa, R. T., Lechevalier, M. P. \& Lechevalier, H. A. (1984). Saccharothrix: a new genus of the Actinomycetales related to Nocardiopsis. Int J Syst Bacteriol 34, 426-431.

Labeda, D. P., Hatano, K., Kroppenstedt, R. M. \& Tamura, T. (2001). Revival of the genus Lentzea and proposal for Lechevalieria gen. nov. Int J Syst Evol Microbiol 51, 1045-1050.

Lechevalier, M. P. \& Lechevalier, H. (1970). Chemical composition as a criterion in the classification of aerobic actinomycetes. Int J Syst Bacteriol 20, 435-443.

Lechevalier, M. P. \& Lechevalier, H. A. (1980). The chemotaxonomy of actinomycetes. In Actinomycete Taxonomy, Special Publication 6, pp. 227-291. Arlington, VA: Society for Industrial Microbiology.

Lechevalier, M. P., De Bièvre, C. \& Lechevalier, H. A. (1977). Chemotaxonomy of aerobic actinomycetes: phospholipid composition. Biochem Syst Ecol 5, 249-260.

Lu, Z., Liu, Z., Wang, L., Zhang, Y., Qi, W. \& Goodfellow, M. (2001). Saccharopolyspora flava sp. nov. and Saccharopolyspora thermophila sp. nov., novel actinomycetes from soil. Int J Syst Evol Microbiol 51, 319-325.

Marmur, J. \& Doty, P. (1962). Determination of the base composition of deoxyribonucleic acid from its thermal denaturation temperature. J Mol Biol 5, 109-118.

Minnikin, D. E., Alshamaony, L. \& Goodfellow, M. (1975). Differentiation of Mycobacterium, Nocardia and related taxa by 
thin-layer chromatographic analysis of whole-organism methanolysates. J Gen Microbiol 88, 200-204.

Minnikin, D. E., O’Donnell, A. G., Goodfellow, M., Alderson, G., Athalye, M., Schaal, K. \& Parlett, J. H. (1984). An integrated procedure for the extraction of bacterial isoprenoid quinones and polar lipids. J Microbiol Methods 2, 233-241.

Mordarska, H., Mordarski, M. \& Goodfellow, M. (1972). Chemotaxonomic characters and classification of some nocardioform bacteria. J Gen Microbiol 71, 77-86.

Rainey, F. A., Ward-Rainey, N., Kroppenstedt, R. M. \& Stackebrandt, E. (1996). The genus Nocardiopsis represents a phylogenetically coherent taxon and a distinct actinomycete lineage: proposal of Nocardiopsaceae fam. nov. Int J Syst Bacteriol 46, 1088-1092.

Sasser, M. (1990). Identification of Bacteria by Gas Chromatography of Cellular Fatty Acids, MIDI Technical Note 101. Newark, DE: MIDI.

Shirling, E. B. \& Gottlieb, D. (1966). Methods for characterization of Streptomyces species. Int J Syst Bacteriol 16, 313-340.

Stackebrandt, E., Rainey, F. A. \& Ward-Rainey, N. (1997). Proposal for a new hierarchic classification system, Actinobacteria classis nov. Int J Syst Bacteriol 47, 479-491.
Thompson, J. D., Gibson, T. J., Plewniak, F., Jeanmougin, F. \& Higgins, D. G. (1997). The CLUSTAL_X windows interface: flexible strategies for multiple sequence alignment aided by quality analysis tools. Nucleic Acids Res 25, 4876-4882.

Wayne, L. G., Brenner, D. J., Colwell, R. R., Grimont, P. A. D., Kandler, O., Krichevsky, M. I., Moore, L. H., Moore, W. E. C., Murray, R. G. E. \& other authors (1987). International Committee on Systematic Bacteriology. Report of the ad hoc committee on reconciliation of approaches to bacterial systematics. Int $J$ Syst Bacteriol 37, 463-464.

Wu, C., Lu, X., Qin, M., Wang, Y. \& Ruan, J. (1989). Analysis of menaquinone compound in microbial cells by HPLC. Microbiology [English translation of Microbiology (Beijing)] 16, 176-178.

Zhang, J., Zhang, Y., Xiao, C., Liu, Z. \& Goodfellow, M. (2002). Rhodococcus maanshanensis sp. nov., a novel actinomycete from soil. Int J Syst Evol Microbiol 52, 2121-2126.

Zhang, J., Liu, Z. \& Goodfellow, M. (2003). Nocardia caishijiensis sp. nov., a novel soil actinomycete. Int J Syst Evol Microbiol 53, 999-1004.

Zhou, Z.-H., Liu, Z.-H., Qian, Y.-D., Kim, S. B. \& Goodfellow, M. (1998). Saccharopolyspora spinosporotrichia sp. nov., a novel actinomycete from soil. Int J Syst Bacteriol 48, 53-58. 